УДК 615.015.14:615.453.6:615.324

DOI https://doi.org/10.11603/2312-0967.2021.1.11940

\title{
ДОСЛІДЖЕННЯ ВПЛИВУ ПРИРОДИ ДОПОМІЖНИХ РЕЧОВИН НА ПОКАЗНИКИ ЯКОСТІ ТАБЛЕТОК ІЗ ЛІОФІЛІЗОВАНИМ ПОРОШКОМ ТРУТНЕВОГО ГОМОГЕНАТУ
}

\author{
Т. А. Грошовий, Б. В. Павлюк, М. Б. Чубка, І. П. Стечишин, М. М. Добринчук \\ Тернопільський національний медичний університет імені І. Я. Горбачевського мОз \\ України \\ bohdana.vons@gmail.com
}

ІНФОРМАЦІЯ

Надійшла до редакції / Received: 21.01.2021

Після доопрацювання / Revised: 29.01.2021

Прийнято до друку / Accepted: 03.02.2021

\section{Ключові слова:}

математичне планування

експерименту;

таблетки;

гомогенат;

ліофілізація.

\begin{abstract}
АНОТАЦІЯ
Мета роботи. Вивчення впливу допоміжних речовин (ДР) на фрармакотехнологічні показники порошкових мас і таблеток на основі ліофілізованого порошку трутневого гомогенату з метою розробки складу таблеток.

Матеріали і методи. Активний фрармацевтичний інгредієнт - ліофілізований порошок трутневого гомогенату, а також ДР, які розділені на 5 груп за фрункціональним призначенням. Таблетки отримували методом прямого пресування. Дослідження впливу ДР на фрармако-технологічні показники порошкових мас і таблеток проводили методами, регламентованими ДФУ.

Результати й обговорення. Дослідження проведено на основі п'ятифакторного експерименту на підставі гіпер-греко-латинського квадрату 5х5. Вивчено вплив ДР різних груп, а саме, зразків мікрокристалічної целюлози (МКЦ), наповнювачів на основі цукрів, розпушувачів, ковзних (регуляторів вологи) та змащувальних речовин на процес пресування таблеток із ліосілізованим порошком трутневого гомогенату. Результати дослідження показують, що на насипну густину порошкових мас, кут природного укосу, процес пресування, середню масу та однорідність маси таблеток найбільше впливають ковзні речовини (регулятори вологи). Розпушувальні речовини $€$ визначальними за впливом на час розпадання таблеток.

Для прийняття рішення про вибір оптимальних ДР використано узагальнені показники - фрункції бажаності та корисності.

Висновок. Вивчено вплив 25-ти ДР на фрармако-технологічні показники порошкових мас та таблеток із ліофілізованим порошком трутневого гомогенату. За сукупністю вивчених показників відібрано кращі поєднання ДР $з$ метою подальшого вивчення їх впливу: Neusilin US 2, Neusilin UFL 2, кальцію фросфат двоосновний (фактор D); натрію крохмальгліколят і натрію карбоксиметилкрохмаль (фрактор С); натрію лаурилсульфат і кальцію стеарат (фактор E); Prosolv SMCC 90 та МКЦ 102 (фрактор A); Ludipress та Emdex dextrates (фрактор B).
\end{abstract}

Вступ. Останнім часом великий інтерес у виробництві лікарських засобів спостерігається щодо речовин природного походження, які проявляють різну фармакологічну активність та характеризуються високим по- казником безпеки. До таких природних речовин відносять продукти бджільництва, одним із яких $€$ трутневий гомогенат. Комплекс наявних біологічно активних речовин зумовлює ряд фрармакологічних характерис-

ISSN 2312-0967. Фармацевтичний часопис. 2021. № 1 
тик даного продукту бджільництва, зокрема, наявність антиоксидантної, іммунотропної, адаптогенної, анаболічної, актопротекторної дії [1]. Відомо, що за різноманітністю вітамінного складу гомогенат займає перше місце серед усіх продуктів бджільництва, випереджаючи навіть маточне молочко [2-4]. Дослідження вітчизняних науковців довели цінність продуктів бджільництва та препаратів на їхній основі, які проявляють різнобічну фрармакологічну активність [5-7].

На даний час препарати на основі трутневого гомогенату найбільш широко представлені на фрармацевтичних ринках Румунії, Китаю, Японії у вигляді настойок, таблеток, кремів $[8,9]$. Трутневий гомогенат є перспективним харчовим продуктом та активним фрармацевтичним інгредієнтом у фармацевтичній технології.

Одним із пріоритетних шляхів розвитку сучасної фрармації $€$ розробка твердих лікарських фрорм на основі речовин природного походження, які характеризуються достатньою ефективністю та безпечністю в застосуванні, а тому цікавим із погляду технології таблетованих фрорм є трутневий гомогенат у вигляді ліофрілізованого порошку, якому притаманний широкий спектр фрармакологічної активності [2-4].

Мета роботи. Вивчення впливу ДР на фрармакотехнологічні показники порошкових мас та таблеток із ліофілізованим порошком трутневого гомогенату 3
Фармацевтична технологія, біофармація, гомеопатія Pharmaceutical technology, biopharmacy, homeopathy метою відбору кращих ексципієнтів для обґрунтування складу таблеток, які отримували методом прямого пресування.

Матеріали і методи. Для отримання експериментальних серій таблеток із ліофілізованим порошком трутневого гомогенату використовували ДР із різними технологічними характеристиками, які об'єднані у 5 груп за фрункціональним призначенням та рекомендуються для використання при отриманні таблеток методом прямого пресування. Перелік ДР, які вивчали при створенні таблеток із порошком трутневого гомогенату, наведено в таблиці 1.

Порошкові суміші для таблетування готували за загальними правилами змішування багатокомпонентних порошкових мас. Пресування таблеток здійснювали на лабораторному однопуансонному таблетному пресі. При цьому оцінювали процес пресування таблеток із врахуванням зовнішнього вигляду та можливих десректів на поверхні таблеток та сили виштовхування. Порошкові маси та отримані таблетки досліджували за фрармако-технологічними показниками, регламентованими ДФУ для твердих лікарських фрорм [10]. Порошкову масу вивчали за такими показниками, як насипна густина до та після усадки, кут природного укосу. Таблетки оцінювали за їхньою середньою масою, однорідністю маси, стійкістю до

\section{Таблиця 1}

Допоміжні речовини, які вивчали при розробці складу таблеток із ліофілізованим порошком трутневого гомогенату методом прямого пресування

\begin{tabular}{|c|c|}
\hline Фактори & Рівні фракторів \\
\hline А - ДР різних зразків МКЦ & $\begin{array}{l}a_{1}-\text { МКЦ } 102 \\
a_{2}-\text { МКЦ } 200 \\
a_{3}-\text { МКЦ } 500 \\
a_{4}-\text { Prosolv SMCC } 50 \\
a_{5}-\text { Prosolv SMCC } 90 \\
\end{array}$ \\
\hline В - наповнювачі на основі цукрів & $\begin{array}{l}\mathrm{b}_{1}-\text { Compri Sugar } \mathrm{O} \\
\mathrm{b}_{2}-\text { Emdex dextrates } \\
\mathrm{b}_{3}-\text { Ludipress } \\
\mathrm{b}_{4}-\text { Pearlitol 100SD Mannitol } \\
\mathrm{b}_{5}-\text { Di-Pac Direct }\end{array}$ \\
\hline C - розпушуючі речовини & $\begin{array}{l}\text { c }_{1} \text { - крохмаль кукурудзяний } \\
\text { c }_{2}-\text { натрію кроскармелоза } \\
\text { c }_{3}-\text { натрію крохмальгліколят } \\
\text { c }_{4}-\text { натрію карбоксиметилкрохмаль } \\
\text { c }_{5} \text { крохмаль прежелатинізований }\end{array}$ \\
\hline D - ковзні речовини (регулятори вологи) & $\begin{array}{l}\mathrm{d}_{1}-\text { Emcompress } \\
\mathrm{d}_{2}-\text { кальцію фроссрат двоосновний } \\
\mathrm{d}_{3}-\text { Neusilin US } 2 \\
\mathrm{~d}_{4}-\text { Neusilin UFL } 2 \\
\mathrm{~d}_{5}-\text { Arbocel P } 290 \\
\end{array}$ \\
\hline E - змащувальні речовини & $\begin{array}{l}\mathrm{e}_{1}-\text { кальцію стеарат } \\
\mathrm{e}_{2}-\text { магнію стеарат } \\
\mathrm{e}_{3}-\text { кислота стеаринова } \\
\mathrm{e}_{4}-\text { натрію лаурилсульфат } \\
\mathrm{e}_{5}-\text { натрію стеарилфумарат }\end{array}$ \\
\hline
\end{tabular}

ISSN 2312-0967. Pharmaceutical review. 2021. № 1 
Фармацевтична технологія, біофармація, гомеопатія Pharmaceutical technology, biopharmacy, homeopathy

роздавлювання, часом розпадання та відсотком стиранності. Кожна серія досліду реалізована у двох повторностях [11].

Для вивчення 5-ти фракторів, кожний із яких взятий на 5 рівнях, використовували п'ятифракторний експеримент на підставі гіпер-греко-латинського квадрату $5 \times 5$ [11].

Експериментальні дані піддавали статистичній обробці методом дисперсійного аналізу. Результати виражали за допомогою ранжованих рядів переваг та стовпчикових діаграм, що показують вплив конкретних ексципієнтів на досліджуваний показник якості.

Результати й обговорення. Ліофілізований порошок трутневого гомогенату характеризується оптимальними срармако-технологічними показниками (насипна густиина до та після усадки - 0,38 г/мл та 0,54 г/мл відповідно, кут природного укосу - 35-40, швидкість течії через насадку 80 с/100 г), необхідними для розробки таких таблеток методом прямого пресування.

Результати дисперсійного аналізу показали, що вплив вивчених фракторів на вільну насипну густину до усадки можна розмістити в такій послідовності: $\mathrm{D}>\mathrm{B}>\mathrm{E}>\mathrm{A}>\mathrm{C}>$ res.

Вплив природи ковзних речовин (регуляторів вологи) на насипну густину порошкових мас до усадки ілюструє такий ряд переваг: $\mathrm{d}_{4}>\mathrm{d}_{3}>\mathrm{d}_{2}>\mathrm{d}_{1}>\mathrm{d}_{5}$

Найбільше значення насипної густини порошкових мас спостерігається при використанні Neusilin US 2 та Neusilin UFL 2, які мають суттєву перевагу над кальцію фросфратом двоосновним, Emcompress та Arbocel P 290.

Вплив природи наповнювачів на основі цукрів (фрактор В) на насипну густину порошкових мас до усадки можна охарактеризувати таким рядом переваг: Compri Sugar O (0,501 г/мл) > Emdex dextrates $(0,499$ г/мл) $=$ Di-Pac Direct $(0,499$ г/мл) > Pearlitol 100SD Mannitol (0,499 г/мл) > Ludipress (0,499 г/мл)

Вплив змащувальних речовин на насипну густину порошкових мас до усадки виражає такий ранжований ряд переваг: натрію стеарилфумарат (0,521 г/мл) $>$ кислота стеаринова (0,506 г/мл) > натрію лаурилсульфрат $(0,496$ г/мл) > кальцію стеарат $(0,489$ г/мл) > магнію стеарат (0,485 г/мл).

Вплив ДР групи зразків МКЦ на насипну густину порошкових мас до усадки відображає такий ряд переваг: Prosolv SMCC 90 (0,529 г/мл) > Prosolv SMCC $50(0,498$ г/Мл) > МКЦ 102 (0,497 г/мл) > МКЦ $200(0,490$ г/Мл) > МКЦ 500 (0,485 г/мл).

Вивчені розпушувачі за впливом на насипну густину порошкових мас до усадки можна розмістити в такій послідовності: натрію крохмальгліколят $(0,494$ г/мл) > крохмаль прежелатинізований $(0,489$ г/мл) > натрію карбоксиметилкрохмаль (0,485 г/мл) > крохмаль кукурудзяний $(0,484$ г/мл) > натрію кроскармелоза (0,481 г/мл).
Результати дисперсійного аналізу експериментальних даних із визначення впливу ДР різних груп на значення насипної густини порошкових мас після усадки показали, що всі вивчені фрактори є статистично значущими: $D>B>A>E>C$.

Найбільше на насипну густину порошкових мас після усадки впливає природа ковзних речовин (регуляторів вологи), так Neusilin UFL 2 має суттєву перевагу над іншими речовинами даної групи (Neusilin US 2, Emcompress, кальцію фросфрат двоосновний та Arbocel P 290).

Порівняльний ряд переваг для ДР на основі цукрів за впливом на насипну густину порошкових мас після усадки має такий вигляд: Di-Pac Direct $(0,697$ г/мл) > Compri Sugar O $(0,689$ г/мл) $>$ Emdex dextrates $(0,682$ г/мл) > Ludipress (0,636 г/мл) > Pearlitol 100SD Mannitol (0,632 г/мл).

Вплив природи зразків МКЦ на насипну густину порошкових мас після усадки ілюструє такий ряд переваг: МКЦ 200 (0,676 г/мл) = МКЦ 102 (0,676 г/мл) > МКЦ 500 (0,671 г/мл) > Prosolv SMCС 50 (0,670 г/мл) > Prosolv SMCC 90 (0,643 г/мл).

Змащувальні речовини впливають на насипну густину порошкових мас після усадки таким чином: натрію стеарилфумарат $(0,683$ г/мл) > кислота стеаринова $(0,670$ г/мл) > магнію стеарат $(0,666$ г/мл) > кальцію стеарат $(0,665$ г/мл) > натрію лаурилсульфрат (0,652 г/мл).

Вивчені розпушувачі за впливом на насипну густину порошкових мас після усадки можна розмістити в такій послідовності: натрію крохмальгліколят (0,678 г/мл) > натрію кроскармелоза $(0,667$ г/мл) > крохмаль прежелатинізований $(0,665$ г/мл) > натрію карбоксиметилкрохмаль (0,664 г/мл) > крохмаль кукурудзяний (0,663 г/мл).

Результати дисперсійного аналізу експериментальних даних показали статистичну значущість фракторів D > C > A при незначущості фракторів B і E за впливом на значення кута природного укосу.

Ковзні речовини (регулятори волги) впливають на кут природного укосу таким чином: Neusilin US 2 > Neusilin UFL $2>$ кальцію фоосфат двоосновний > Emcompress > Arbocel P 290. Якщо враховувати, що порошкові маси $з$ плинністю менше $40^{\circ}$ забезпечують пряме пресування таблеток, то можна зробити висновок, що з більшістю із вивчених ДР можна отримати таблетки методом прямого пресування.

Вплив розпушувачів на кут природного укосу порошкових мас із порошком трутневого гомогенату можна відобразити таким рядом переваг: натрію карбоксиметилкрохмаль $\left(33,3^{\circ}\right)>$ натрію крохмальгліколят $\left(35,4^{\circ}\right)>$ крохмаль прежелатинізований $\left(36,5^{\circ}\right)>$ крохмаль кукурудзяний $\left(37,0^{\circ}\right)>$ натрію кроскармелоза $\left(37,4^{\circ}\right)$.

Допоміжні речовини на основі МКЦ впливають на кут природного укосу досліджуваних порошкових мас таким чином: Prosolv SMCC $90\left(35,0^{\circ}\right)>$ МКЦ 102

ISSN 2312-0967. Фармацевтичний часопис. 2021. № 1 
$\left(35,8^{\circ}\right)>$ МКЦ $500\left(36,6^{\circ}\right)>$ МКЦ $200\left(36,8^{\circ}\right)>$ Prosolv SMCC $50\left(37,4^{\circ}\right)$.

Процес пресування таблеток різних серій на лабораторній таблетній машині проходив неоднаково. При оцінці процесу пресування враховували повноту засипання матриці, прилипання таблеток до пуансонів, наявність дефектів на поверхні спресованих таблеток. Результати дисперсійного аналізу експериментальних даних за вказаним відгуком показали такий ряд переваг досліджуваних фракторів: D > E > $\mathrm{A}>\mathrm{B}>\mathrm{C}$.

Ранжований ряд переваг впливу ковзних речовин (регуляторів вологи) на процес пресування таблеток виглядає таким чином: $\mathrm{d}_{3}>\mathrm{d}_{2}>\mathrm{d}_{4}>\mathrm{d}_{5}>\mathrm{d}_{1}$ (рис. 1).

Визначено, що найбільш суттєво на процес пресування таблеток із ліофілізованим порошком трутневого гомогенату впливає Neusilin US 2, якому поступаються кальцію фоосфат двоосновний, Neusilin UFL 2, а також суттєво поступаються Arbocel P 290 та Emcompress. У всіх серіях дослідів, в яких використовували Neusilin US 2, процес пресування проходив добре.

Вплив природи змащувальних речовин на процес пресування таблеток можна охарактеризувати таким рядом переваг: натрію лаурилсульфат (3,9 бала) > кальцію стеарат (3,4 бала) > натрію лаурилсульфат (3,3 бала) > кислота стеаринова (3,0 бала) > магнію стеарат (2,8 бала).

Вивчені ДР на основі МКЦ за впливом на процес пресування можна розмістити в такій послідовності: Prosolv SMCC 90 (3,9 бала) > МКЦ 500 (3,3 бала) > МКЦ 200 (3,2 бала) > МКЦ 102 (3,1 бала) > Prosolv SMCC 50 (2,9 бала).

ДР на основі цукрів за впливом на процес пресування можна розмістити в такий ряд переваг: Pearlitol 100SD Mannitol (3,5 бала) = Ludipress (3,5 бала) >
Фармацевтична технологія, біофармація, гомеопатія Pharmaceutical technology, biopharmacy, homeopathy

Compri Sugar O (3,2 бала) > Emdex dextrates (3,1 бала) > Di-Pac Direct (2,9 бала).

Вплив розпушувачів на процес пресування таблеток ілюструє даний ранжований ряд переваг: натрію крохмальгліколят (3,5 бала) = натрію карбоксиметилкрохмаль (3,5 бала) > крохмаль прежелатинізований (3,4 бала) > крохмаль кукурудзяний $(3,1$ бала) > натрію кроскармелоза (2,9 бала).

Результати статичного аналізу експериментальних даних із вивчення впливу досліджуваних фракторів та їхніх рівнів на показник однорідності маси таблеток показали, що характер впливу вивчених фракторів ілюструє така послідовність: $\mathrm{D}>\mathrm{A}>\mathrm{C}>\mathrm{E}>$ res при статистичній незначущості фрактора В.

Вплив фрактора D та його рівнів на однорідність маси таблеток із порошком трутневого гомогенату зображено на рисунку 2

За даними рисунка 2, найкращу однорідність маси отриманих таблеток забезпечують Neusilin US 2 ( $\pm 1,37 \%)$, Neusilin UFL 2 ( $\pm 2,26 \%)$ та кальцію фросфрат двоосновний $( \pm 2,43 \%)$, які мають суттєву перевагу над Emcompress ( $\pm 3,16 \%$ ) та Arbocel P 290 $(5,06 \%)$

Ранжований ряд переваг для зразків МКЦ має такий вигляд: $\mathrm{a}_{1}>\mathrm{a}_{3}>\mathrm{a}_{5}>\mathrm{a}_{4}>\mathrm{a}_{2}$. Визначено, що таблетки були найбільш однорідними при використанні МКЦ 102 ( $\pm 2,18 \%)$, яка має перевагу над МКЦ $500( \pm 2,57 \%)$, Prosolv SMCC 90 ( $\pm 2,84 \%)$, Prosolv SMCC $50( \pm 2,84 \%)$ та МКЦ $200( \pm 4,06 \%)$.

Розпушувальні речовини за впливом на однорідність маси таблеток із порошком трутневого гомогенату утворюють такий ряд переваг: натрію крохмальгліколят $( \pm 2,20 \%)>$ крохмаль прежелатинізований $( \pm 2,29 \%)>$ крохмаль кукурудзяний $( \pm 2,74 \%)>$ натрію кроскармельоза $( \pm 3,12 \%)>$ натрію карбоксиметилкрохмаль ( $\pm 3,93 \%)$.

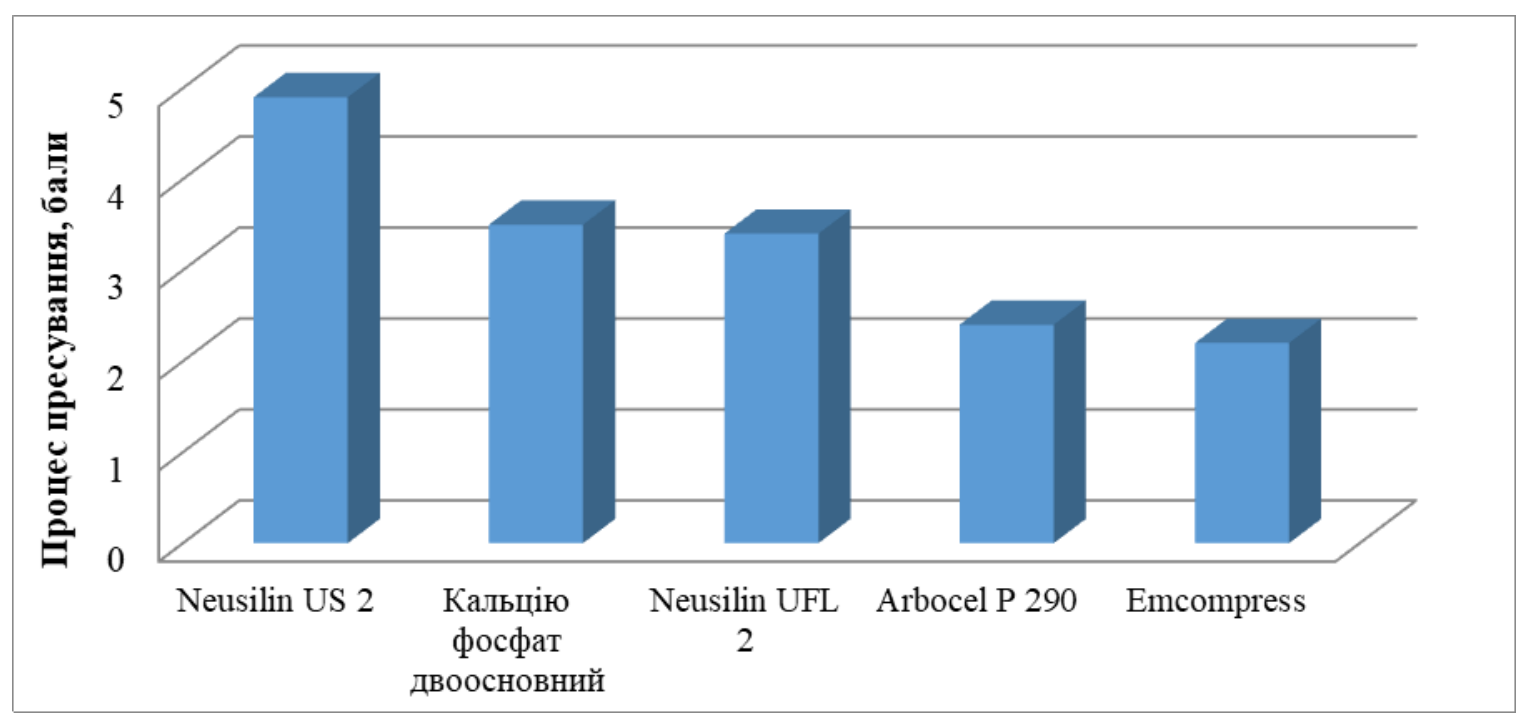

Рис. 1. Вплив ковзних речовин (регуляторів вологи) на процес пресування таблеток із ліофілізованим порошком трутневого гомогенату.

ISSN 2312-0967. Pharmaceutical review. 2021. № 1 
Фармацевтична технологія, біофармація, гомеопатія

Pharmaceutical technology, biopharmacy, homeopathy

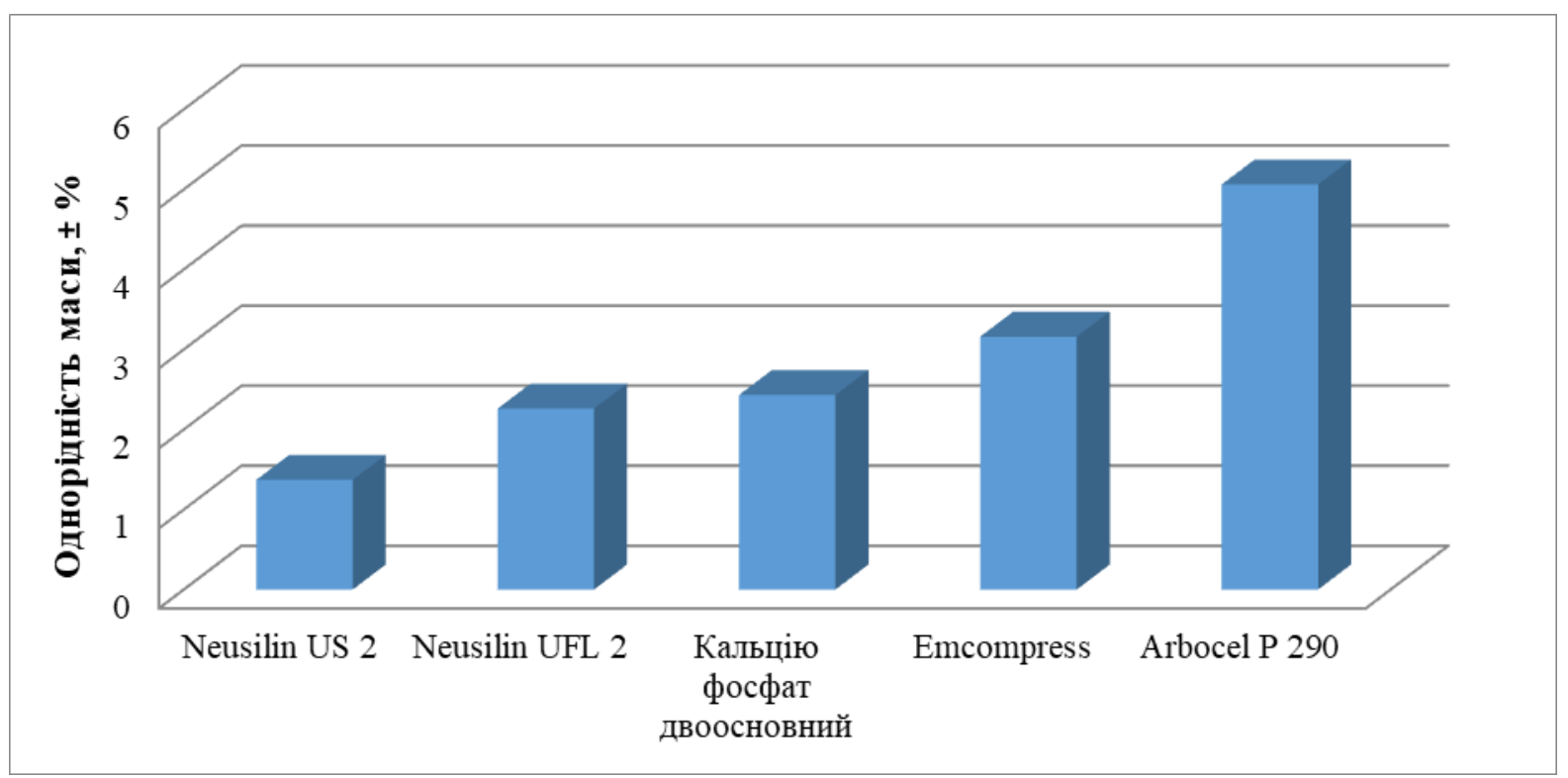

Рис. 2. Вплив природи ковзних речовин на однорідність маси таблеток із ліофілізованим порошком трутневого гомогенату.

Вплив природи змащувальних речовин на однорідність маси таблеток можна охарактеризувати таким рядом переваг: натрію лаурилсульфрат ( $\pm 2,10 \%)$ $>$ магнію стеарат $( \pm 2,43 \%)>$ натрію стеарилорумарат $( \pm 2,59 \%)>$ кислота стеаринова $( \pm 3,36 \%)>$ кальцію стеарат $( \pm 3,80 \%)$.

Вплив вивчених фракторів на стійкість таблеток до роздавлювання ілюструє такий ряд переваг: D >A > B
> C. На рисунку 3 відображено вплив рівнів найбільш значущого фрактора D (ковзних речовин) на стійкість таблеток до роздавлювання, ранжований ряд переваг яких має такий вигляд: Neusilin UFL $2(76,6$ H) > Neusilin US $2(54,6$ H) > Emcompress $(38,6$ H) > кальцію фросфрат двоосновний (33,2 H) > Arbocel P 290 (29,4 H).

Вплив різних зразків МКЦ на стійкість таблеток до роздавлювання виглядає таким чином: Prosolv SMCC

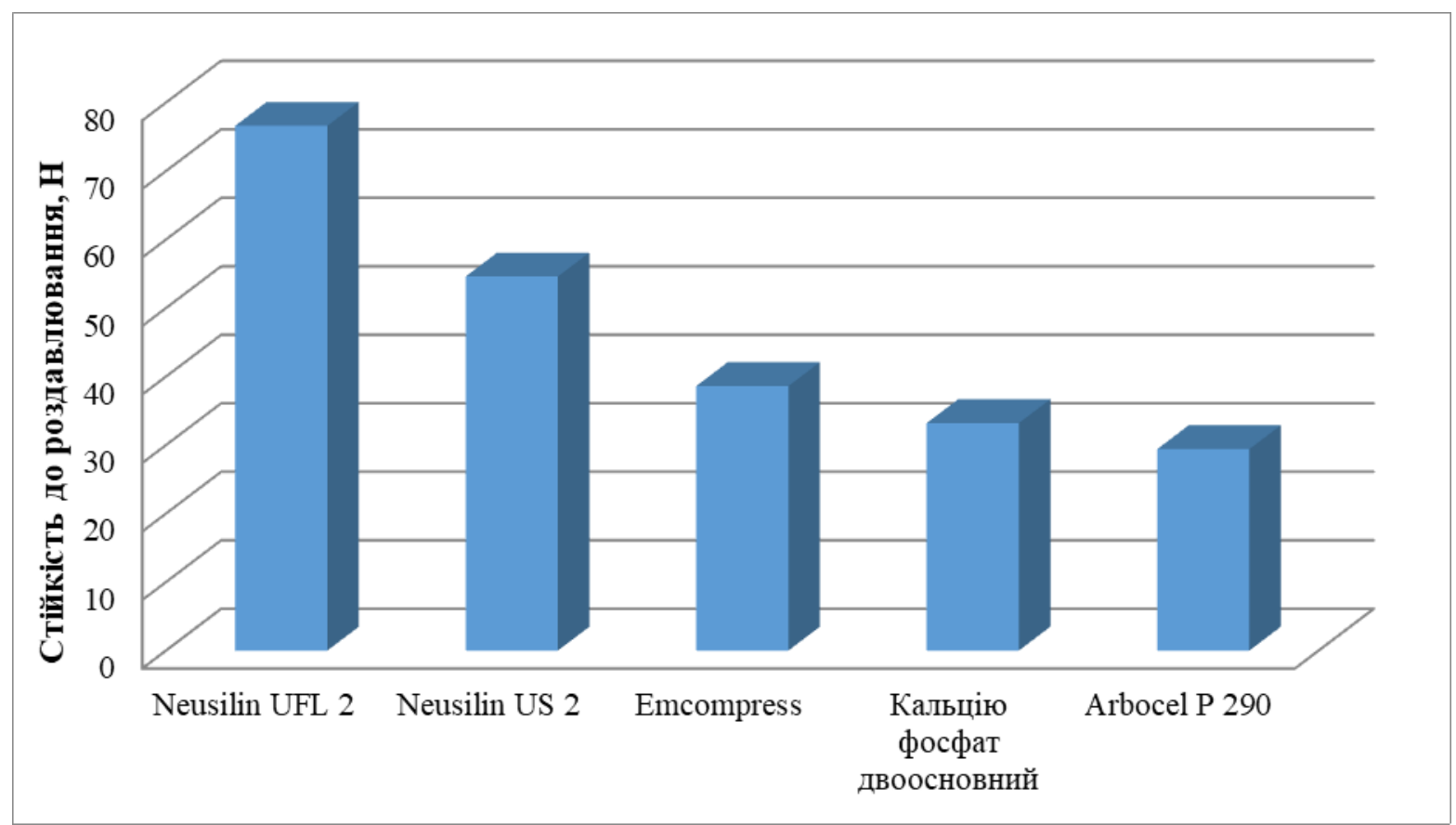

Рис. 3. Вплив ковзних речовин на стійкість таблеток до роздавлювання з ліофрілізованим порошком трутневого гомогенату.

ISSN 2312-0967. Фармацевтичний часопис. 2021. № 1 
$90(54,26 \mathrm{H})>$ Prosolv SMCC $50(50,30 \mathrm{H})>$ МКЦ 500 $(48,80$ Н $)>$ МКЦ $200(40,60$ Н) > МКЦ $102(38,60$ Н).

Найбільш стабільний вплив на показник стійкості таблеток до роздавлювання проявляли змащувальні речовини, природа яких не суттєво впливає на міцність, а тому ранжований ряд можна зобразити таким чином: кислота стеаринова $(54,9$ H) > кальцію стеарат $(47,1$ H) > магнію стеарат $(45,3$ H) > натрію лаурилсульфрат > $(44,1$ H) > натрію стеарилфумарат (41 H).

Аналогічно до впливу змащувальних речовин на стійкість таблеток до роздавлювання проявили себе і наповнювачі на основі цукрів, ранжований ряд переваг для яких виглядає таким чином: Emdex dextrates $(52,7$ H) > Di-Pac Direct $(49,2 \mathrm{H})>$ Ludipress $(48,4 \mathrm{H})>$ Compri Sugar O $(46,5 \mathrm{H})>$ Pearlitol 100SD Mannitol $(37,6 \mathrm{H})$.

Серед вивчених розпушувачів найбільше значення стійкості до роздавлювання таблеток забезпечував крохмаль кукурудзяний (51,9 H), який мав перевагу над крохмалем прежелатинізованим (47,4 H), натрію крохмальгліколятом $(45,9$ H), натрію кроскармелозою $(43,9$ H) та натрію карбоксиметилкрохмалем $(42,2 \mathrm{H})$.

Ранжований ряд переваг для відображення впливу якісних фракторів на розпадання таблеток виглядає таким чином: C > A > D > E > B. Найбільш впливовим $€$ фрактор C (розпушувачі), вплив рівнів якого зображено на рисунку 4.

Отже, за даними рисунка 4, найшвидше розпадалися таблетки, які в своєму складі містили натрію крохмальгліколят $(11,4$ хв) та натрію карбоксиметилкрохмаль (11,8 хв), а найдовше - таблетки, до складу яких входили крохмаль прежелатинізований (15,9хв),
Фармацевтична технологія, біофармація, гомеопатія Pharmaceutical technology, biopharmacy, homeopathy натрію кроскармелоза (19,8 хв), крохмаль кукурудзяний (43,8 хв).

Щодо впливу різних зразків МКЦ на час розпадання таблеток, то найменший час розпадання мали таблетки, до складу яких входили МКЦ 102 (11,4хв) та МКЦ 200 (14,4 хв). Дані ДР мають незначні переваги над Prosolv SMCC 90 (19,8 хв), МКЦ 500 (20,8 хв), та більш суттєві над Prosolv SMCC 50 (33,3 хв).

Ранжований ряд переваг для ковзних речовин за позитивним впливом на час розпадання таблеток має такий вигляд: кальцію фосфрат двоосновний $(13,0$ Хв) $>$ Emcompress (15,2 Хв) > Neusilin US 2 $(17,0$ Хв $)>$ Neusilin UFL 2 (27,3 Хв) > Arbocel P 290 $(30,2 \times B)$.

Вплив змащувальних речовин на час розпадання таблеток можна проілюструвати таким рядом переваг: кальцію стеарат (14,6 хв) > натрію стеарилфрумарат (16,8 хв) > натрію лаурилсульсат (19,5 хв) > магнію стеарат (20,4 хв) > кислота стеаринова (31,3 хв).

Вплив досліджуваних наповнювачів на розпадання таблеток має такий ряд переваг: Ludipress (18,1 хв) $>$ Emdex dextrates (18,4 хв) > Di-Pac Direct $(19,7$ хв) > Compri Sugar O (21,3 хв) > Pearlitol 100SD Mannitol $(25,2 \times в)$.

При проведенні досліджень 3 вибору раціональних ДР при створенні таблеток із ліофілізованим порошком трутневого гомогенату порошкові маси та готові таблетки контролювали за багатьма відгуками. Для прийняття рішення про вибір оптимальних ДР раціонально використовувати узагальнений показник - фрункцію бажаності.

Інфрормація, яка отримана на підставі дисперсійного аналізу експериментальних даних показала, що найголовнішими відгуками є процес пресування та-

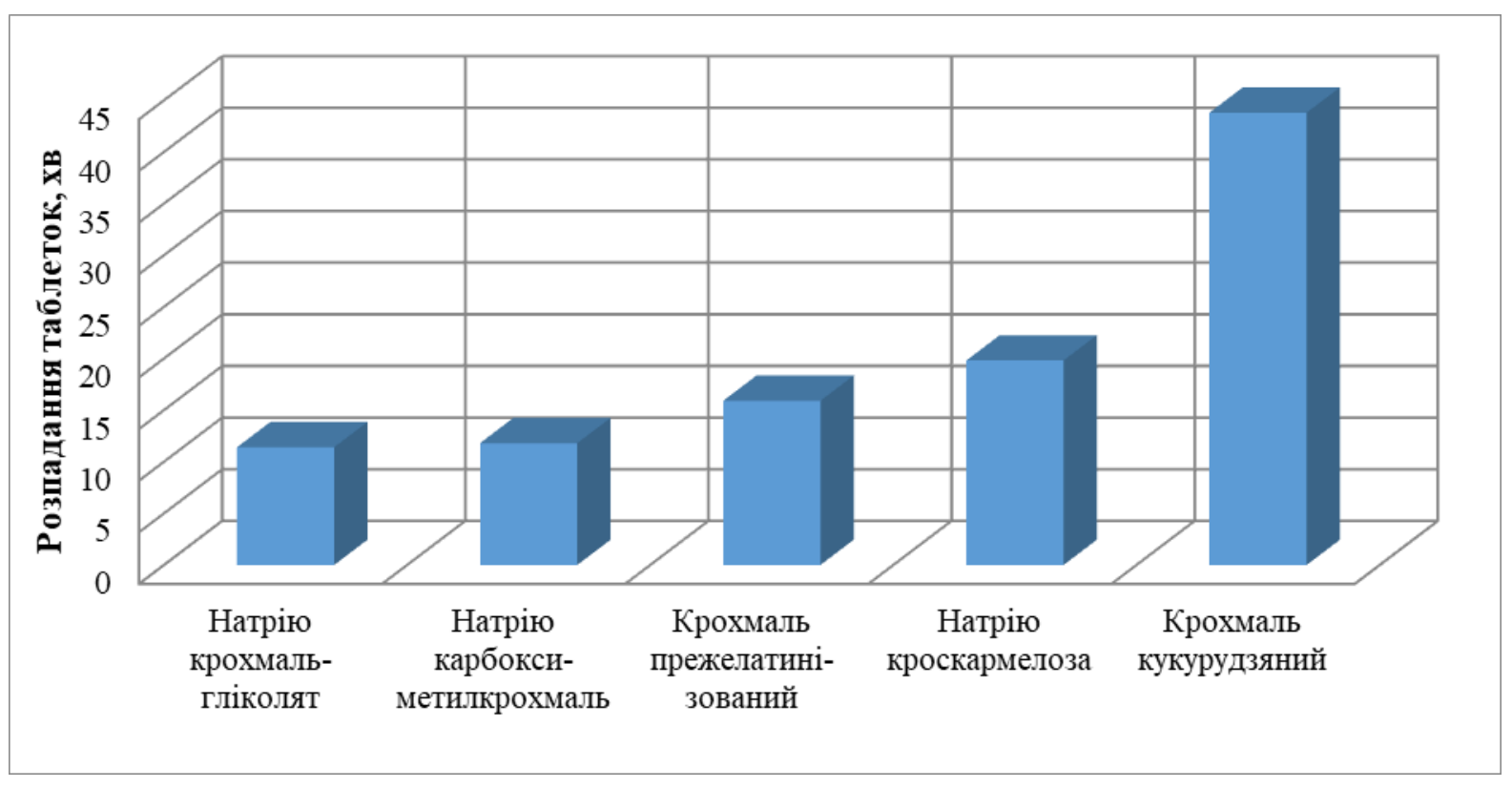

Рис. 4. Вплив розпушувачів на час розпадання таблеток із ліофілізованим порошком трутневого гомогенату.

ISSN 2312-0967. Pharmaceutical review. 2021. № 1 
Фармацевтична технологія, біофармація, гомеопатія Pharmaceutical technology, biopharmacy, homeopathy

блеток, однорідність маси, стійкість до роздавлювання, час розпадання та стиранність. Інші отримані відгуки дають інфрормацію про властивості порошкових мас та отриманих таблеток, однак на прийняття висновку щодо кращих ДР не впливають.

Для побудови та аналізу узагальненої функції бажаності перетворювали вимірювані значення основних відгуків у безрозмірну шкалу бажаності. Оскільки відсоток втрати в масі при визначенні стиранності досліджуваних таблеток був невисоким, тому цей відгук на даному етапі досліджень не враховували.

Результати дисперсійного аналізу даних фрункції бажаності показали, що вплив вивчених фракторів можна розмістити в такій послідовності: фрактор D > фрактор C > res > фрактор E при статистичній незначущості фракторів А і В.

Вплив природи ковзних речовин на функцію бажаності має такий вигляд: Neusilin US 2 > Neusilin UFL 2 $>$ кальцію фоосфат двоосновний > Emcompress > Arbocel P 290.

При використанні функції бажаності виникала ситуація, коли за одним із відгуків (наприклад, стійкість до роздавлювання) отримували найкращий результат, а за іншим (наприклад, час розпадання) - найгірший. В такому випадку значення функції бажаності дорівнювало 0. Тому пошук кращих поєднань ДР здійснювали за допомогою функції корисності, при використанні якої підсумовується кількість місць за відгуками, при цьому за найкраще значення надавалось 1-ше місце і т. д.

Вплив ковзних речовин на значення фуункції корисності $€$ аналогічним, як і для фрункції бажаності. Отже, для вибору ДР із вивченої групи раціонально більш детально вивчити Neusilin US 2, Neusilin UFL 2 та кальцію фоосфат двоосновний.

Вплив природи розпушувачів на функцію бажаності можна розмістити в такий ряд переваг: натрію карбоксиметилкрохмаль > натрію крохмальгліколят > крохмаль прежелатинізований > натрію кроскармелоза > крохмаль кукурудзяний.
Тоді як на функцію корисності їхній вплив виглядає таким чином: натрію крохмальгліколят > крохмаль кукурудзяний > натрію карбоксиметилкрохмаль > натрію кроскармелоза > крохмаль прежелатинізований. Наведений ряд переваг відрізняється від ряду переваг для функції бажаності. При використанні функції бажаності крохмаль кукурудзяний виявився непридатним для отримання таблеток методом прямого пресування, тому для подальшого вивчення відібрано натрію крохмальгліколят та натрію карбоксиметилкрохмаль.

Вивчені змащувальні речовини за впливом на фрункції бажаності та корисності можна охарактеризувати таким рядом переваг: натрію лаурилсульфат > кальцію стеарат > натрію стеарилфумарат > кислота стеаринова > магнію стеарат, а тому для подальшого дослідження 3 даної групи ексципієнтів відібрано натрію лаурилсульфрат та кальцію стеарат.

Результати дисперсійного аналізу даних фрункції бажаності для зразків МКЦ показали статистичну незначущість (при $p=0,05$ ) вивченого фрактора. Тоді як при $p=0,25$ за впливом зразків МКЦ на фрункцію бажаності відібрано Prosolv SMCC 90 і МКЦ 102.

За результатами дисперсійного аналізу визначено, що фрактор В $є$ статистично незначущим за впливом на фрункцію бажаності. Проте за поєднаними результатами функцій бажаності та корисності відібрано Ludipress та Emdex dextrates для подальших досліджень.

Висновки. Проведені дослідження показали, що за сукупністю даних функцій бажаності та корисності для подальших досліджень раціонально використати такі ДР: Neusilin US 2, Neusilin UFL 2, кальцію фосфрат двоосновний (фактор D); натрію крохмальгліколят і натрію карбоксиметилкрохмаль (фактор C), натрію лаурилсульфрат і кальцію стеарат (фактор E); Prosolv SMCC 90 та МКЦ 102 (фрактор A); Ludipress та Emdex dextrates (фрактор B).

Конфлікт інтересів: відсутній.

Conflicts of interest: authors have no conflict of interest to declare.

\section{STUDY OF THE INFLUENCE OF THE NATURE OF EXCIPIENTS ON THE QUALITY INDICATORS OF TABLETS WITH LYOPHILIZED DRONE BROOD HOMOGENATE POWDER}

\section{T. A. Hroshovyi, B. V. Pavliuk, M. B. Chubka, I. P. Stechyshyn, M. M. Dobrynchuk}

\section{Horbachevsky Ternopil National Medical University bohdana.vons@gmail.com}

The aim of the work. Study of the effect of excipients on the pharmaco-technological parameters of tablets based on the lyophilized powder of drone brood homogenate in order to develop the composition of tablets.

Materials and Methods. The active pharmaceutical ingredient is a lyophilized powder of drone brood homogenate, as well as excipients, which are divided into 5 groups by functional purpose. The tablets were obtained by direct compression. Study of the influence of excipients on the pharmaco-technological parameters of powder masses and tablets regulated by the State Pharmacopoeia of Ukraine.

ISSN 2312-0967. Фармацевтичний часопис. 2021. № 1 
Results and Discussion. The research was conducted based on a five-factor experiment based on the Hyper-GraecoLatin square $5 \times 5$. The influence of excipients of different groups, namely, samples of microcrystalline cellulose (MCC), fillers based on sugars, leavening agents, sliding substances (moisture regulators) and lubricants on the process of pressing tablets with lyophilized drone brood homogenate powder has been studied. The results of the study show that the bulk density, the angle of repose, the compression process, the average weight and the uniformity of weight are most affected by sliding substances (moisture regulators). Looseners are decisive in the effect on the disintegration time of tablets.

To make a decision on the choice of optimal excipients used generalized indicators - the functions of desirability and usefulness.

Conclusions. The effect of 25 excipients on the pharmaco-technological parameters of tablets with lyophilized drone brood homogenate powder was studied. According to the set of studied indicators, the best combinations of excipients were selected in order to further study their impact: Neusilin US 2, Neusilin UFL 2, calcium phosphate dibasic (factor D); sodium starch glycolate and sodium carboxymethyl starch (factor C); sodium lauryl sulfate and calcium stearate (factor E); Prosolv SMCC 90 and MCC 102 (factor A); Ludipress and Emdex dextrates (factor B).

Key words: design of experiment; tablets; drone brood; lyophilization.

\title{
ИССЛЕДОВАНИЕ ВЛИЯНИЯ ПРИРОДЫ ВСПОМОГАТЕЛЬНЫХ ВЕЩЕСТВ НА ПОКАЗАТЕЛИ КАЧЕСТВА ТАБЛЕТОК С ЛИОФИЛИЗИРОВАННЫМ ПОРОШКОМ ТРУТНЕВОГО ГОМОГЕНАТА
}

\author{
Т. А. Грошовый, Б. В. Павлюк, М. Б. Чубка, И. П. Стечишин, Н. Н. Добрынчук \\ Тернопольский национальный медицинский университет имени И. Я. Горбачевского мз Украины \\ bohdana.vons@gmail.com
}

Цель роботы. Изучение влияния вспомогательных веществ (ВВ) на фрармако-технологические показатели порошковых масс и таблеток на основе лиофилизированного порошка трутневого гомогената с целью разработки состава таблеток.

Материалы и методы. Действующее вещество - лиосилизированный порошок трутневого гомогената, а также ВВ, которые разделены в 5 групп по фрункциональному назначению. Таблетки получали методом прямого прессования. Исследование ВВ на фармако-технологические показатели порошковых масс и таблеток, регламентированными ГФ Украины.

Результаты й обсуждение. Исследование проведены на основе пятифакторного эксперимента на основании гипергреко-латинского квадрата 5х5. Изучено влияние ВВ различных групп, а именно, образцов микрокристаллической целлюлозы (МКЦ), наполнителей на основе сахаров, разрыхлителей, скользящих (регуляторов влаги) и смазочных веществ на процесс прессования таблеток с лиосилизированным порошком трутневого гомогената.

Результаты исследования показывают, что на насыпную плотность порошковых масс, угол естественного откоса, процесс прессования, среднюю массу и однородность массы таблеток наиболее влияют скользящие вещества (регуляторы влаги). Разрыхляющие вещества являются определяющими по воздействию на время распада таблеток.

Для принятия решения о выборе оптимальных ВВ использовано обобщенные показатели - фрункции желательности и полезности.

Виводы. Изучено влияние 25-ти ВВ на фрармако-технологические показатели порошковых масс и таблеток с лиофилизированным порошком трутневого гомогената. По совокупности изученных показателей отобраны лучшие сочетания BB с целью дальнейшего изучения их воздействия: Neusilin US 2, Neusilin UFL 2, кальция фоссрат двухосновной (фрактор D); натрия крахмалгликолят и натрия карбоксиметилкрахмал (фрактор C); натрия лаурилсульфат и кальция стеарат (фактор E); Prosolv SMCC 90 и МКЦ 102 (фрактор A); Ludipress и Emdex dextrates (фрактор В).

Ключевые слова: математическое планирование эксперимента; таблетки; гомогенат; лиосилизация.

\section{Список бібліографічних посилань}

1. Nutritional composition of Apis mellifera Drones from Korea and Denmark as a potential sustainable alternative food source. S. Ghosh, H. Y. Sohn, S. J. Pyo et al. Comparison between developmental stages. Foods. 2020. No. 9. P. 389.

2. Sidor E., Dzugan M. Drone brood homogenate as natural remedy for treating health care problem. A Scien- tific and Practical Approach. Molecules. 2020. No. 25. P. 1-15.

3. Bałka'nska R., Karadjova I., Ignatova M. Comparative analyses of chemical composition of royal jelly and drone brood. Bulg. Chem. Commun. 2014. No. 46. P. 412-416.

4. Маннапов А. Г., Мишуковская Г. С., Ларионова О. С.

ISSN 2312-0967. Pharmaceutical review. 2021. № 1 
Фармацевтична технологія, біофармація, гомеопатія Pharmaceutical technology, biopharmacy, homeopathy

Аминокислотный состав трутневого расплода при варроатозе. Пчеловодство. 2005. №2. С. 20-21.

5. Технологія виготовлення екстемпоральних лікарських апіпрепаратів і їх застосування в фрармації, медицині та косметології: метод. рек. / авториуклад. : О. І. Тихонов, Т. Г. Ярних, С. О. Тихонова та ін. ; за ред. О. І. Тихонова. Харків, 2016. 75 с.

6. Тихонов О. І., Богдан Н. С., Шпичак О. С. Перспектива створення напрямку "Альтернативне лікарське забезпечення населення екстемпоральними препаратами продуктів бджільництва". Зб. наук. праць співроб. НМАПО імені П. Л. Шупика. 2014. № 23 (3). С. 429-433.

7. Розробка технології комплекного апіфрітопрепарату "Апісед" у фрормі капсул загальнозміцнювальної та седативної дії / Шпичак О. С. та ін. Актуальні питання фрармацевтичної і медичної науки та практики. 2017. № 3 (25). С. 355-363.

\section{References}

1. Ghosh S, Sohn HY, Pyo SJ, Jensen AB, Meyer-Rochow VB, Jung $C$. Nutritional composition of Apis mellifera Drones from Korea and Denmark as a potential sustainable alternative food source: Comparison between developmental stages. Foods [serial online]. 2020;9: 389. DOI: 10.3390/foods9040389.

2. Sidor E, Dżugan M. Drone brood homogenate as natural remedy for treating health care problem: a Scientific and practical approach. Molecules [serial online]. 2020;25(23): 1-15. DOI: 10.3390/molecules25235699.

3. Bałkánska R, Karadjova I, Ignatova M. Comparative analyses of chemical composition of royal jelly and drone brood. Bulg Chem Commun. 2014;46: 412-6.

4. Mannapov AG, Mishukovskaya GS, Larionova OS [Amino acid comosition of drone brood in varroasis]. Pchelovodstvo. 2005;2: 20-1. Russian.

5. Tikhonov OI, Yarnykh TG, Tikhonova SO, Bashura OG, Shpychak OS, Bondarenko LO, et al. Technology of manufacturing extemporaneous drugs and their use in pharmacy, medicine and cosmetology: guidelines. [Технологія виготовлення екстемпоральних лікарських апіпрепаратів і їх застосування в фрармації, медицині та косметології: метод. рек.] Kharkiv; 2016. Ukrainian.

6. Tikhonov OI, Bogdan NS, Shpychak OS. Perspective towards the creation "Alternative medical maintenance the population of extemporaneous preparations of bee products". Zb. Nauk. Prats' spivrob. NMAPO P.L. Shupyka. 2014;23(3): 429-33. Ukrainian.
8. Sawczuk R., Karpinska J., Miltyk W. What do we need to know about drone brood homogenate and what is known. J. Ethnopharmacol. 2019. No. 245. 111581.

9. Ulmer M., Smetana S., Heinz V. Utilizing honeybee drone brood as a protein source for food products: Life cycle assessment of apiculture in Germany. Resour. Conserv. Recycl. 2020. No.154. 104576.

10. Державна Фармакопея України: в 3 т. / Державне підприємство «Український науковий фрармакопейний центр якості лікарських засобів». - 2-е вид. - Харків : Державне підприємство «Український науковий фрармакопейний центр якості лікарських засобів», 2014. Т. 1. 1128 с.

11. Математичне планування експерименту при проведенні наукових досліджень у срармації / Грошовий Т. А. та ін. Тернопіль : ТДМУ «Укрмедкнига», 2008. 368 с.

7. Shpychak OS, Tikhonov OI, Koval VM, Bobro SG Shpychak AO. The technology development for the complex Api-phyto product "Apised" in the form of capsules with the restorative andsedative action. Current Issues in Pharmacy and Medicine: Science and Practice. 2017;10(3): 355-63. Ukrainian.

8. Sawczuk R, Karpinska J, Miltyk W. What do we need to know about drone brood homogenate and what is known: Journal of Ethnopharmacology [serial online]. 2019;245:111581. DOI: 10.1016/j.jep.2018.10.042.

9. Ulmer M, Smetana S, Heinz V. Utilizing honeybee drone brood as a protein source for food products: Life cycle assessment of apiculture in Germany. Resour Conserv Recycl. 2020;154. DOI:10.1016/j.resconrec.2019.104576.

10. The State Pharmacopoeia of Ukraine: 1 vol. Kharkiv: Ukrainian Scientific Pharmacopoeia Center of Quality of Medicinal Products. Ed.2. Vol. 1. [Державна Фармакопея України: в 3 т. / Державне підприємство «Український науковий фрармакопейний центр якості лікарських засобів». - 2-е вид.] Kharkiv: Ukrainian Scientific Pharmacopoeia Center of Quality of Medicinal Products; 2015. Ukrainian.

11. Hroshovyi TA, Martsenyuk VP, Kucherenko LI, Vronska LV, Huryeyeva CM. Mathematical planning of experiment in pharmacy. [Математичне планування експерименту при проведенні наукових досліджень в формації] Ternopil: Ternopil State Medical University; 2008. Ukrainian.

\section{Відомості про авторів}

Грошовий Т. А. - д. фрармац. наук, завідувач кафедри управління та економіки фрармації з технологією ліків, Тернопільський національний медичний університет імені І. Я. Горбачевського МОЗ України, Тернопіль, Україна. E-mail: grochovuy@ukr.net, ORCID 0000-0002-6427-2158

Павлюк Б. В. - д. фрілос. фрармац., асистент кафедри управління та економіки фрармації 3 технологією ліків, Тернопільський національний медичний університет імені І. Я. Горбачевського МОЗ України, Тернопіль, Україна. E-mail: bohdana.vons@gmail.com, ORCID 0000-0003-1276-0114 
Фармацевтична технологія, біофармація, гомеопатія

Pharmaceutical technology, biopharmacy, homeopathy

Чубка М. Б. - канд. фрармац. наук, доцент кафедри фрармації ФПО, Тернопільський національний медичний університет імені І. Я. Горбачевського МОЗ України, Тернопіль, Україна. E-mail: chubkacom@gmail.com, ORCID 00000002-5666-5496

Стечишин І. П. - канд. біол. наук, асистент кафредри управління та економіки фрармації з технологією ліків, Тернопільський національний медичний університет імені І. Я. Горбачевського МОЗ України, Тернопіль, Україна. E-mail: stechyshyn@tdmu.edu.ua, ORCID 0000-0002-5360-2780

Добринчук М. М. - магістрант кафедри управління та економіки фрармації з технологією ліків, Тернопільський національний медичний університет імені І. Я. Горбачевського МОЗ України, Тернопіль, Україна. E-mail: dobrynchuk_mymy@tdmu.edu.ua

\section{Information about the authors}

Hroshovyi T. A. - DSc (Pharmacy), Professor, Head of the Department of Pharmacy Management, Economics and Technology, I. Horbachevsky Ternopil National Medical University, Ternopil, Ukraine. E-mail: grochovuy@ukr.net, ORCID 00000002-6427-2158

Pavliuk B. V. - PhD (Pharmacy), Assistant of the Department of Pharmacy Management, Economics and Technology, I. Horbachevsky Ternopil National Medical University, Ternopil, Ukraine. E-mail: bohdana.vons@gmail.com, ORCID 00000003-1276-0114

Chubka M. B. - PhD (Pharmacy), Associate Professor, Department of Pharmacy, Faculty of Postgraduate Education, I. Horbachevsky Ternopil National Medical University, Ternopil, Ukraine. E-mail: chubkacom@gmail.com, ORCID 00000002-5666-5496

Stechyshyn I. P. - PhD (Biology), Assistant of the Department of Pharmacy Management, Economics and Technology, I. Horbachevsky Ternopil National Medical University, Ternopil, Ukraine. E-mail: stechyshyn@tdmu.edu.ua, ORCID 00000002-5360-2780

Dobrynchuk M. M. - graduate student of the Department of Pharmacy Management, Economics and Technology, I. Horbachevsky Ternopil National Medical University, Ternopil, Ukraine. E-mail: dobrynchuk_mymy@tdmu.edu.ua 